\title{
UNIQUE SHELL UTILIZATION BY REEF-FLAT HERMIT CRABS IN GUAM, MICRONESIA*
}

With 2 Plates and 2 Tables

$$
\text { by }
$$

\section{Akira ASAKURA}

(Amakusa Marine Biological Laboratory of Kyushu University**)

$$
\text { グアム島（ミクロネシア）産ヤドカリの特異な貝殼利用について }
$$

図版 2，表 2

$$
\text { 朝倉彰 }
$$

九州大学理学部附属天草臨海実験所 熊本県天草郡苓北町富岡 干863-25

\begin{abstract}
Calcinus latens is the hermit crab widely distributed in the Indo-Pacific region. Many authors have reported that $C$. latens uses gastropod shells having regular whorls and showing regular conical shape, however I found in a coral reef of Guam that many individuals of $C$. latens used shells of irregular whorls or peculiar shapes, such as the shells of Vermetidae, Cypraeidae, Conidae and they are highly damaged. These shells are significantly heavier than the shells of normal type and sometimes their center of gravity is various. It has been reported that heavier shells influence the growth rate and clutch size of hermit crabs and that unbalanced shells restrict the locomotion ability of hermit crabs. Thus this condition is regarded as worse for $C$. latens, and may result from the scarcity of normal shells in the reef.
\end{abstract}

\section{Introduction}

Hermit crabs are unique among higher crustaceans, because they generally utilize gastropod shells as portable shelters. Gastropods have various forms of shells, but generally hermit crabs only use certain kinds, i.e. those which have regular coilings (whorls) and show regular conical shapes, such as the shells of the Trochidae, Turbinidae, Cerithiidae, and Muricidae. Their center of gravity is near the center axis

* Contribution no. 315 from the Amakusa Marine Biological Laboratory, Kyushu University.

** 836-25, Tomioka, Reihoku-cho, Amakusa-gun, Kumamoto-ken, Japan. 
of the shells, and hermit crabs can easily maintain their balance in the shell utilization.

However, gastropods having shells of irregular whorls or peculiar shapes are also known, and they are utilized by specific species of hermit crabs. For example, species of Conidae have a thick, heavy shell with a thin, elongated aperture. They have a very narrow inner space in relation to their weight. Clibanarius eurysternus utilizes shells of Conidae (Mryake, 1982); its body is dorso-ventrally flattened and fits the aperture of cone shells. Vermetid shells have sometimes irregular shapes of whorls and are cemented fast to rock surface. Calcinus verrilli specifically utilizes them (MARKHAM, 1977). Cowrie shells (family Cypraeidae) have no obvious whorl structure and are pouch-like. No hermit crabs use the cowrie shells specifically.

The hermit crab, Calcinus latens is the Indo-Pacific species, and generally uses shells having regular whorls (ABRAMS, 1981a, b; WoOsTER, 1978; ORIANS and King, 1964 ; HazletT, 1970). However I found in the population of C. latens on Guam Island of Micronesia that many individuals used the shells of Conidae, Cypraeidae, and Vermetidae. In this paper I report the manner of utilization of such irregular-type shells in that population as well as the relationship between the weight of the crabs and that of their utilized shells.

The author wish to express my thanks to Prof. Taiji KIKUCHI of Amakusa Marine Biological Laboratory of Kyushu University for critical reading of the manuscript and to Kiyoshi Raymond Nakamura of A.M.B.L. for improving the English text.

\section{Methods}

Samplings were done in Tuamon Bay of Guam Island, Micronesia, in June 1986. In the intertidal zone of this site, three hermit crabs commonly occur; Clibanarius humilis in the upper intertidal zone, Calcinus latens in the middle intertidal zone, and Calcinus gaimardi in the lower intertidal zone. At low tide of spring tide I collected hermit crabs there, randomly picking them up by hand. These hermit crabs were fixed by $10 \%$ formalin solution and brought to the laboratory. The hermit crabs and their shells were identified to species, dried up at $60^{\circ} \mathrm{C}$ for 120 hours, and weighed on a micro balancer.

In this paper I define the shells of Conidae, Cypraeidae, Vermetidae and highly damaged shells as the shells of peculiar type. Then I define the shells having regular whorls as the shells of normal type, which are used by most species of hermit crabs.

\section{Results}

Many examples of use of peculiar-type shells were found in Calcinus latens. In Clibanarius humilis, no individuals utilized the shells of peculiar type, and only one 
case of the peculiar-shell use was found in Calcinus gaimardi. Thus I report about the cases of $C$. latens.

Fig. 1 (Pl. IV) shows vermetid shells utilized by $C$. latens. The shells had detached from the rock surface and were covered with a thick, calcareous substance. Since the shells have irregular whorls, it seems difficult for the hermit crabs to balance themselves. In the photographs, the major chelipeds of $C$. latens can be observed.

The utilization of cowrie shells by $C$. latens are shown in Fig. 2 (Pl. IV). The aperture is very narrow in relation to its inner volume, and only small crabs can get into the shells. In these photographs, individuals of $C$. latens retreated deeply into the inner part of shells in the fixation and can not be observed. The shells were covered sparsely with calcareous, polychaetous tubes and coralline algae.

Fig. $3(\mathrm{Pl}$. V) shows the utilization of cone shells by $C$. latens. Only small crabs can get into the shells, because the shells have very narrow aperture.

Fig. 4 (Pl. V) shows the utilization of highly damaged shells by C. latens. These shells had been broken and have holes of several size. Normally, hermit crabs mainly use the body whorl (the first whorl from the aperture) of the shell, however these crabs used the parietal whorl (the second whorl from the aperture) or the third (or more) whorls.

In this study area, the shell of normal type, Canarium mutabilis, dominated the molluscan fauna, and the hermit crab mainly used it. I measured the dry weight of the hermit crabs and Canarium mutabilis they occupied (Table 1). The ratio of the shell weight divided by the crab weight ranges from 10.802 to 40.556 , and the mean value is 24.184 (s.d.=8.775). And I also measured this ratio in the utilization of shell of peculiar type; the shell of Conidae, Cypraeidae, and Vermetidae and highly damaged

Table 1. Use of shells of normal type (see definition in the methods) by the hermit crab, Calcinus latens; the relationship between dry weight of the crabs and that of their utilized shells.

\begin{tabular}{|c|c|c|c|c|}
\hline No. & Shell species & $\begin{array}{l}\text { shell weight } \\
\text { in } \mathrm{g}[\mathrm{S}]\end{array}$ & $\begin{array}{l}\text { crab weight } \\
\text { in } \mathrm{g}[\mathrm{C}]\end{array}$ & {$[\mathrm{S}] /[\mathrm{C}]$} \\
\hline 1. & Canarium mutabilis & 0.7959 & 0.0325 & 24.489 \\
\hline 2. & " & 0.6611 & 0.0286 & 23.115 \\
\hline 3. & " & 0.6352 & 0.0333 & 19.075 \\
\hline 4. & " & 0.5541 & 0.0513 & 10.802 \\
\hline 5. & " & 0.8666 & 0.0284 & 30.514 \\
\hline 6. & " & 0.6234 & 0.0336 & 18.580 \\
\hline 7. & " & 1.1582 & 0.0284 & 40.556 \\
\hline 8. & " & 1.1869 & 0.0327 & 36.297 \\
\hline 9. & " & 0.4597 & 0.0297 & 15.478 \\
\hline \multirow[t]{3}{*}{10.} & " & 0.8140 & 0.0355 & 22.930 \\
\hline & & & & 24.184 \\
\hline & & & & 8.775 \\
\hline
\end{tabular}


Table 2. Use of the shells of peculiar type (see definition in the methods) by the hermit crab, Calcinus latens; the relationship between the dry weight of crabs and that of their utilized shells.

\begin{tabular}{cccc} 
No. Shell species & $\begin{array}{c}\text { shell weight } \\
\text { in } \mathrm{g}[\mathrm{S}]\end{array}$ & $\begin{array}{c}\text { crab weight } \\
\text { in } \mathrm{g}[\mathrm{C}]\end{array}$ & {$[\mathrm{S}] /[\mathrm{C}]$} \\
\hline
\end{tabular}

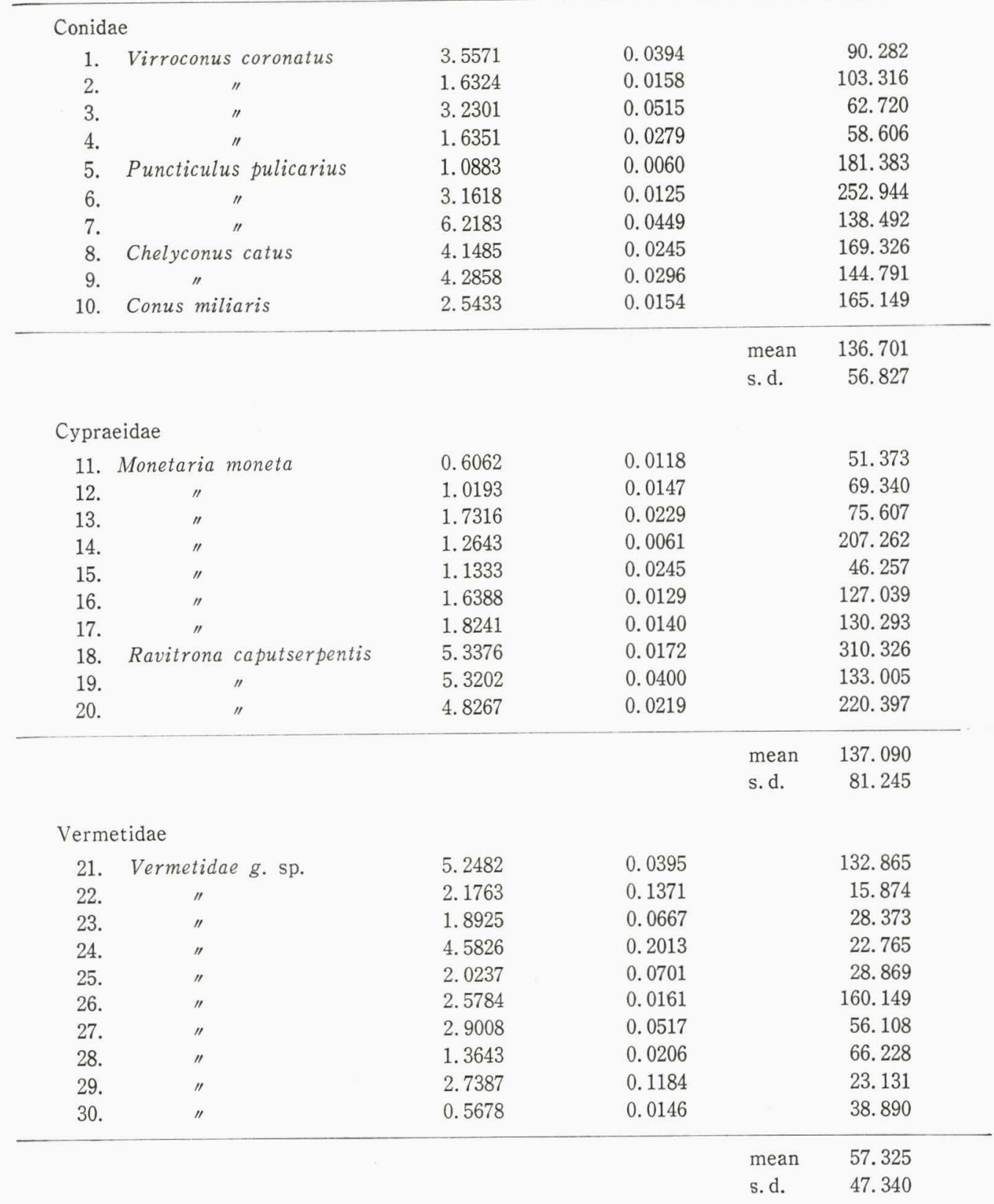


(continued)

\begin{tabular}{|c|c|c|c|c|c|}
\hline No. & Shell species & $\begin{array}{l}\text { shell weight } \\
\text { in } \mathrm{g}[\mathrm{S}]\end{array}$ & $\begin{array}{c}\text { crab weight } \\
\text { in } \mathrm{g}[\mathrm{C}]\end{array}$ & & {$[\mathrm{S}] /[\mathrm{C}]$} \\
\hline \multicolumn{6}{|c|}{ damaged shells } \\
\hline 31. & Drupa ricina & 2.6361 & 0.0125 & & 210.888 \\
\hline 32. & Drupa morum & 7.0274 & 0.0580 & & 121.162 \\
\hline 33. & Drupa glossularia & 0.5940 & 0.0035 & & 169.714 \\
\hline 34. & Mancinella tuberosa & 5.1055 & 0.0418 & & 122.141 \\
\hline 35. & Cararium mutabilis & 0.6869 & 0.0305 & & 22.521 \\
\hline 36. & " & 0.6026 & 0.0166 & & 36.301 \\
\hline 37. & " & 0.5233 & 0.0321 & & 16.302 \\
\hline 38. & Cymatium sp. & 3.1086 & 0.0451 & & 68.927 \\
\hline 39. & " & 1.6815 & 0.0380 & & 44.250 \\
\hline \multirow{3}{*}{\multicolumn{2}{|c|}{ 40. Trochus nilotics }} & 2.4227 & 0.0226 & & 107. 199 \\
\hline & & & & mean & 91.941 \\
\hline & & & & s.d. & 62.158 \\
\hline
\end{tabular}

shells (Table 2). The mean values of the ratio are significantly higher than that in the shell use of the normal type; 136.701 in Conidae $(\mathrm{p}<0.0001, \mathrm{U}=0$, one-tail MannWhitney's U-test), 137.090 in Cypraeidae ( $<<0.0001, \mathrm{U}=0$, one-tail Mann-Whitney's U. test), 57.325 in Vermetidae ( $\mathrm{p}<0.05, \mathrm{U}=25$, one-tail Mann-Whitney's U-test) and 91.941 in damaged shells $(\mathrm{p}<0.025, \mathrm{U}=14$, one-tail Mann-Whitney's U-test). Very high values are observed in the utilization of Cypraeidae, such as 310.326 and 220.397 in Ravitrona captuserpentis and 207.262 in Monetaria moneta, and in the utilization of Conidae, such as 252.944 in Puncticulus pulicarius, as well as in the utilization of damaged shells, such as 210.888 in Drupa ricina.

\section{Discussion}

The shells utilized by Calcinus latens have been frequently reported: Trochus niloticus, Drupa sp., Natica sp., Strombus sp., and Cypraea sp. at Pago Bay and Agat Bay of Guam Island (Wooster, 1982); Clypeomorus morum, Strombus gibberulus luhuanus, Cerithium sp., Monetaria moneta, and Conus sp., etc. in Enewetak Atoll and Guam Island (Abrams, 1981a); Planaxis planicostatus, Cerithium sp., Nerita sp., Turbo sp., Trochus sp., etc. at One Tree Island, Australia (ABRAMs, 1981b); Ergalatax constricus and Reishia luteostoma at Shirahama, Japan (MIYAKe and IMAFuku, 1980).

These suggest that $C$. latens mostly uses and prefers the shells of normal type. Though Wooster (1982) and ABRAMS (1981a) reported that in a few cases this species of the hermit crab also uses the shells of Cypraeidae and Conidae. ABRAMS (1981b) reported in a $C$. latens population in the tropical Pacific that the frequencies of Monetaria moneta (Cypraeidae) and Conus sp. occupied $2.49 \%$ and $4.58 \%$ respectively in the shells utilized by them. 
In this study area, most individuals of $C$. latens use shells of normal types such as Trochus niloticus and Canarium mutabilis, although they also use the shells of Vermetidae, Conidae, and Cypraeidae and highly damaged shells. The utilization frequencies of them are considered to be nearly the same as those in ABRAMS (1981b). These shells are heavier in relation to the body weight of hermit crabs (Table 2) than the shells of the normal type (Table 1). BERTNEss (1981) reported that hermit crabs which use shells of heavier weight and lower internal volume have lower growth rates and lower clutch sizes. Thus the use of shells of the peculiar type can be regarded as a worse condition for the hermit crab from the view point of shell weight.

Since the positions of center of gravity are various in vermetid shells, the crab cannot balance himself easily. This decreases the locomotion ability of the crab and, perhaps, causes serious problems, because locomotion plays an important role for hermit crabs in their acquisition of new shells and food (HAZLETT, 1983) and in their avoiding predation and dessication (REESE, 1969). CoNOver (1978) reported that the alteration of the angle of the shell axis and the position of the shell's center of gravity resulted in an aversion to altered shells by hermit crabs.

Nevertheless, $C$. latens in the Guam population sometimes uses the shells of peculiar type. This may be because the normal shells are very scarce in the reef and the crab are forced to use "worse" shells, as many authors have suggested in several locations (HAZLETT, 1981).

\section{References}

Abrams, P. 1981a. Alternative methods of measuring competition applied to two Australian hermit crabs. Oecologia, $51: 233-239$.

Abrams, P. 1981b. Competition in an Indo-Pacific hermit crab community. Oecologia, 51: 240249.

BertNess, M.D. 1981. The influence of shell-type on hermit crab growth rate and clutch size (Decapoda, Anomura). Crustaceana, 40: 197-205.

Conover, M.R. 1978. The importance of various shell characteristics to the shell-selection behaviour of hermit crabs. J. Exp. Mar. Biol. Ecol., 32: 131-142.

Hazlett, B.A. 1970. Interspecific shell fighting in three sympatric species of hermit crabs in Hawaii. Pacific Science, 24 : 472-482.

Hazlett, B. A. 1981. The behavioral ecology of hermit crabs. Ann. Rev. Ecol. Syst., 12: 1-22.

Hazlett, B.A. 1983. Daily movement in the hermit crabs Clibanarius tricolor and Calcinus tibicen. J. Crust. Biol., 3: 223-234.

Markham, J.C. 1977. Preliminary note on the ecology of Calcinus verrilli, an endemic Bermuda hermit crab occupying attached vermetid shells. J. Zool. Lond., 181: 131-136.

Mryake, S. 1982. Japanese Crustacean Decapods and Stomatopods in Color. I. Macrura, Anomura and Stomatopoda. Hoikusha, Tokyo. $261 \mathrm{pp}+56 \mathrm{pls}$.

Miyake, S. and Imafuku, M. 1980. Hermit crabs from Kii Peninsula I. Nanki Seibutu, 22: 1-7.

Orians, G. H. and KInG, C.E. 1964. Shell selection and invasion rates of some Pacific hermit crabs. Pacific Science, 18: 297-306.

ReEse, E.S. 1969. Behavioral adaptation of intertidal hermit crabs. Am. Zool., 9: 343-355.

Wooster, D.S. 1982. The genus Calcinus (Paguroidea, Diogenidae) from the Mariana Islands including three new species. Micronesica, 18: 121-162. 
ッマジロサンゴヤドカリCalcinus latens は，普通，規則正しく層の巻かれた巻貝を利用し ているが，グアム島において多数の個体が特殊な形態の貝, オオへビガイ科・タカラガイ科・ イモガイ科の貝や, 破損の大きな巻貝の貝殼を利用しているのを観察した。これらは形態が特 異な上, 貝殼内の体積に比べ貝殼の重量が大きく, ヤドカリにとって種々の不都合をもたらす と推測された。 
Plate IV

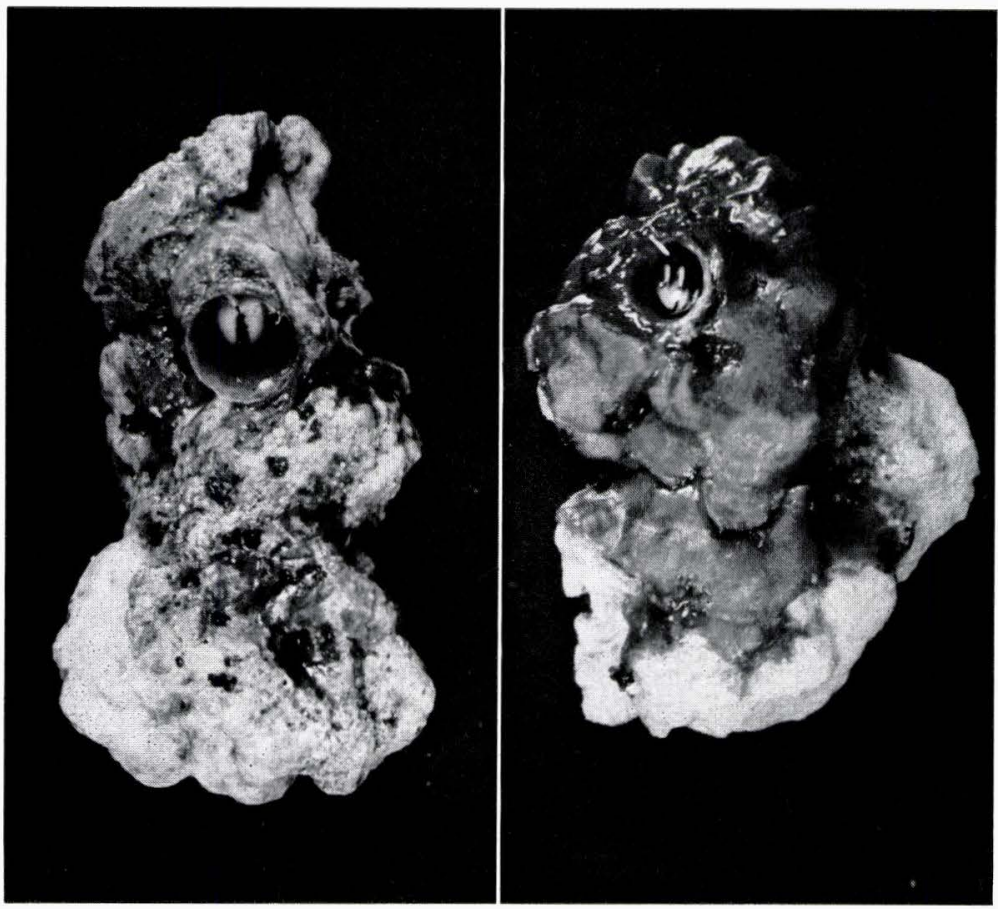

Fig. 1. Utilization of shells of Vermetidae (unidentified species) by Calcinus latens.
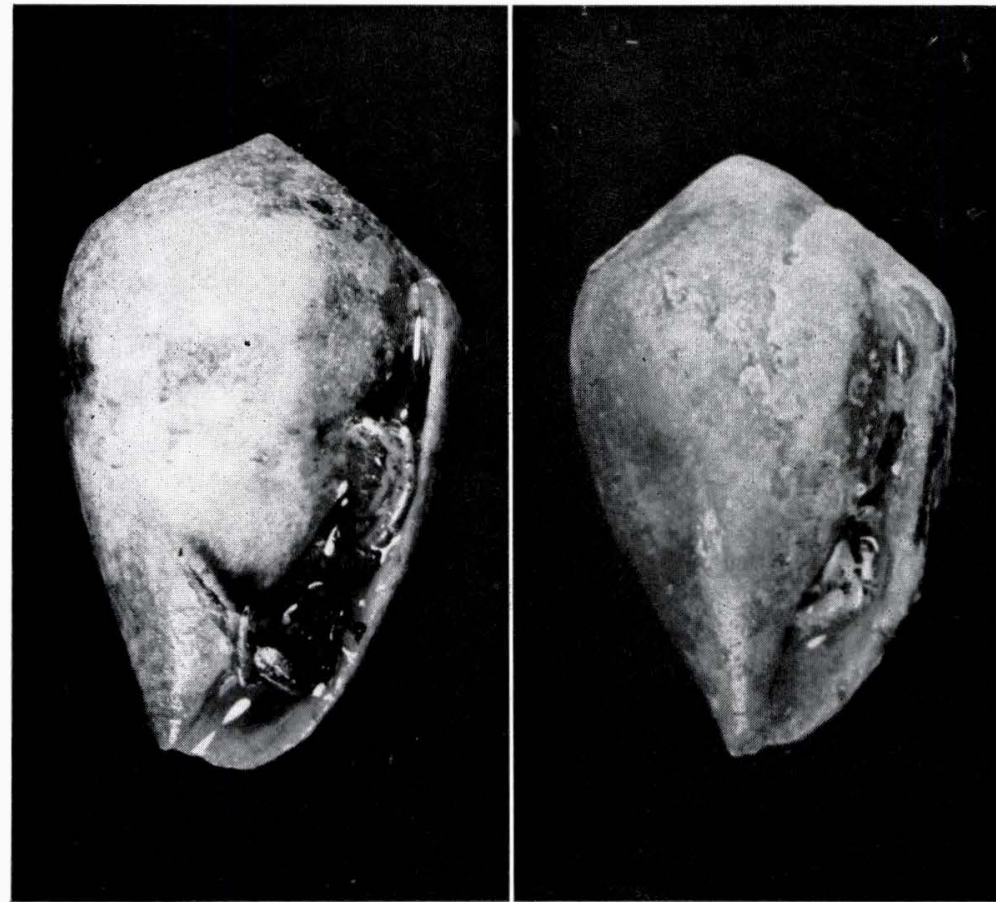

Fig. 2. Utilization of shells of Cypraeidae by C. latens, Monetaria moneta (left) and Ravitrona caputserpentis (right). 
Plate V

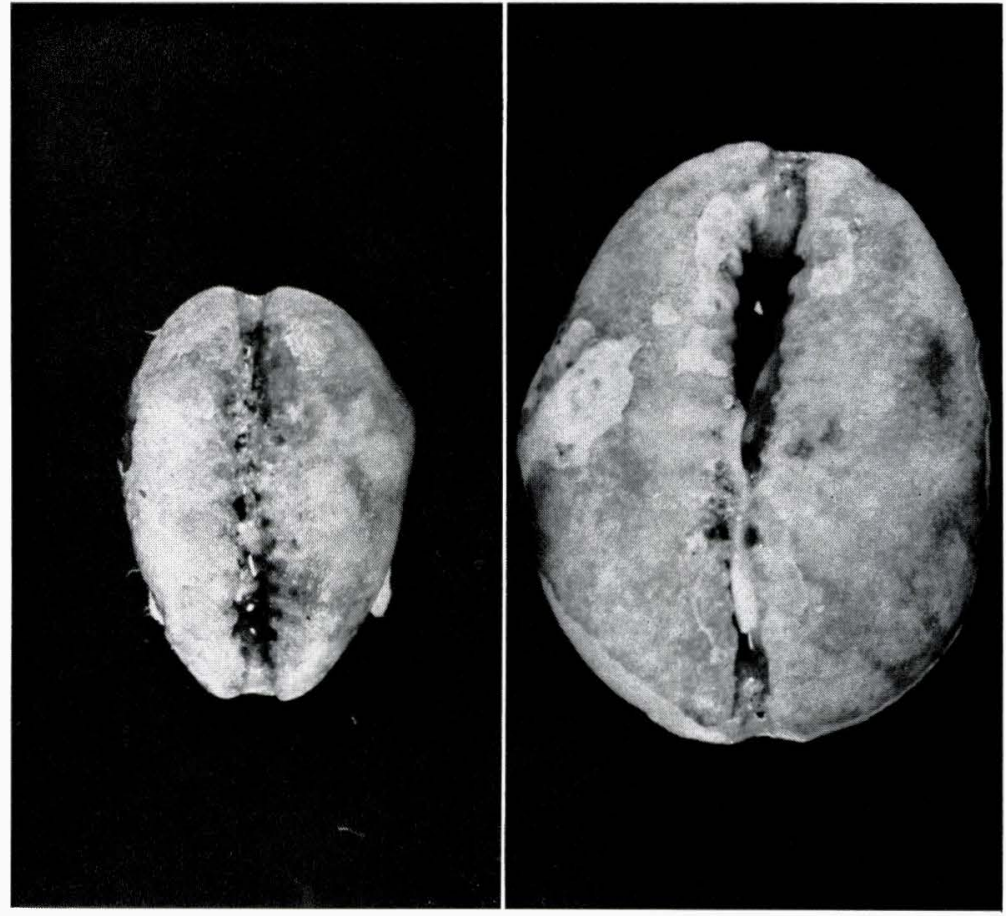

Fig. 3. Utilization of shells of Conidae by C. latens. Chelyconus catus (left) and Virroconus coronatus (right).

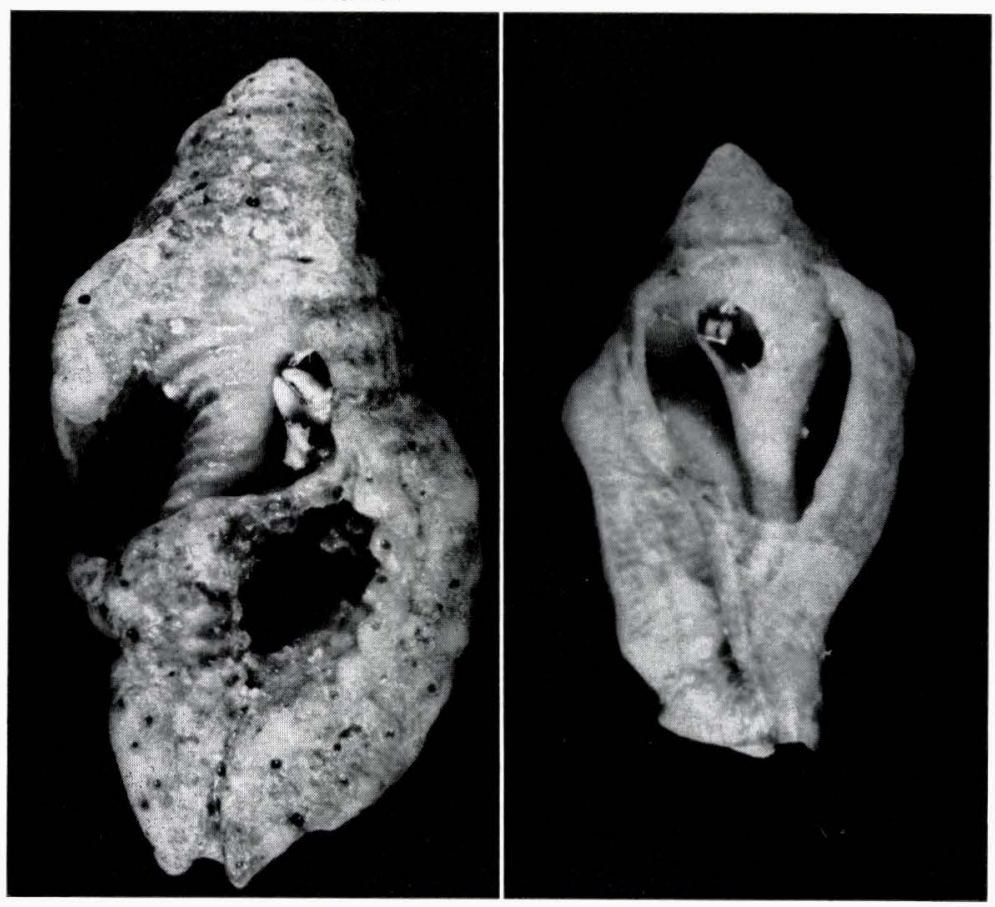

Fig. 4. Utilization of broken shells by $C$. latens, Cymatium sp. (left) and Canarium mutabilis (right). 